\title{
Opredelitev in meje Sredozemlja v Sloveniji po mnenju prebivalcev slovenske Istre
}

\author{
Valentina Brečko Grubar \\ UP FHŠ, Oddelek za geografijo \\ valentina.brecko.grubar@fhs.upr.si \\ Miha Koderman \\ UP FHŠ, Oddelek za geografijo \\ miha.koderman@fhs.upr.si \\ Mojca Poklar \\ UP FHŠ, Oddelek za geografijo \\ mojca.poklar@fhs.upr.si
}

\section{Uvod}

V prispevku predstavljamo rezultate raziskave, pri kateri so sodelovali študenti podiplomskega študijskega programa Geografija UP Fakultete za humanistične študije in se je povezala z vsebino predmeta Sodobni geografski procesi $v$ Sredozemlju. Tema je obsegala poznavanje regionalnih značilnosti Sredozemlja na splošno ter upoštevanje teh lastnosti pri razmejitvi sredozemskega in nesredozemskega območja v Sloveniji. Opredeljevanje regionalnih lastnosti temelji na upoštevanju vrste različnih naravnih in družbenih meril, najceloviteje pa ga običajno dojemajo prebivalci preučevanega območja. Slovenska Istra je del obsredozemske makroregije Slovenije, kjer so pokrajinske lastnosti z lego ob morju, obalnim obsredozemskim podnebjem, ugodnimi pogoji za gojenje oljke, ribiško tradicijo in drugimi elementi še najbližje pravim sredozemskim, zato smo raziskavo opravili med prebivalci štirih istrskih občin. Po zgledu predhodno opravljenih raziskav smo zasnovali anketni vprašalnik, nato pa s tehniko kvotnega vzorčenja pridobili vzorec 351 izpolnjenih vprašalnikov, ki je v relativno visoki meri odražal številčne, prostorske in spolne značilnosti prebivalcev na obravnavanem območju. Poleg vrednotenja ponujenih odgovorov s petstopenjsko lestvico so anketiranci morali na priloženi zemljevid Slovenije izrisati mejo med sredozemskim in nesredozemskim delom. S pridobljenimi odgovori smo preučili, s katerimi identitetami se bolj in s katerimi manj istovetijo, s katerimi elementi naravnega okolja, prehranjevalnimi in ve- 
denjskimi vzorci anketiranci v največji meri povezujejo Sredozemlje ter kaj je bil »vodilni motiv« pri omejevanju Sredozemlja v Sloveniji. Mnenja različnih strok so si enotna, da je Sredozemlje zapletena in težko opredeljiva prostorska tvorba. To so potrdili tudi rezultati naše raziskave.

\section{Geografske opredelitve Sredozemlja}

Pri opredeljevanju tako večplastnega in kompleksnega pojma, kot je Sredozemlje, se posameznik sooči s številnimi dilemami in izzivi. Kot ugotavljajo Staut, Kovačič in Ogrin $(2007,123)$ ter Tandarić idr. (2013), enotnega in enostavnega merila, $\mathrm{s}$ katerim bi lahko $\mathrm{v}$ prostorskem kontekstu razmejili Sredozemlje od ne-Sredozemlja, ni. Sredozemlje je kompleksna prostorska tvorba, katere identiteta se je izoblikovala postopoma od predantike do danes. Zaledne pokrajine Sredozemskega morja so bile območje zgodnje stalne naselitve in kmetijskega obdelovanja tal, tekom kasnejših zgodovinskih obdobij pa območje kolonizacij, preseljevanj, menjav prebivalstva in njihovih kultur (Rotar 1993; Baskar 2002). Mediteranskosti ali sredozemskosti ne moremo opredeliti kot osnovno značilnost Sredozemlja, na osnovi katere bi omejili njegov obseg. Opredelitev mora zajeti fizične in družbeno-kulturne lastnosti prostora ter dojemanje prebivalcev, kot so ugotovili Tandarić idr. (2013).

Na prvi pogled je Sredozemlje lažje opredeliti z naravnogeografskimi oziroma pokrajinskimi lastnostmi, ki pa se pri natančnejšem pregledu prav tako precej razlikujejo. Pokrajina je rezultat součinkovanja naravnih pokrajinskih sestavin, kot so podnebje, površje, kamninska zgradba, vode, prsti, rastlinstvo, in ima v "pravem "Sredozemlju prepoznavno temeljno značilnost, to je prevladujoče zimzeleno rastje, ki gradi gozdove (trdolistni zimzeleni gozd ali sklereja) in še bolj razširjena grmičevja (makijo in garigo). V višjih nadmorskih višinah in na »robnih" predelih pa to postopoma prehaja $v$ listopadno rastje. Pri tem moramo upoštevati še, da je današnje rastlinstvo tudi posledica večtisočletne prisotnosti človeka, izkoriščanja in krčenja gozdov, kmetijske in druge rabe tal (Allen 2001).

Med rastlinskimi vrstami, ki jih povezujemo s Sredozemljem, sta najprepoznavnejši zimzeleni hrast črnika (Quercus ilex) in oljka (Olea europaea), ki je postala eden od simbolov Sredozemlja ter povezovalni člen njegove kulture in okolja. Lastnosti rastlinstva so tesno povezane s podnebnimi pogoji in zgoraj omenjeno rastlinstvo je pokazatelj razmeroma toplih zim brez zmrzali ter poletnega pomanjkanja vlage, na katerega so se rastline na različne načine morale prilagoditi $z$ varčevanjem vode in rastnim 
ciklom (Allen 2001). Za pravo Sredozemlje je namreč značilno podnebje z vročimi poletji in več mesecev trajajočo sušo ter milimi in vlažnimi zimami. Robna območja in višje ležeči predeli imajo že opazno nižje temperature, zmrzal in snežne padavine, izdatnejše in pogostejše padavine, za severni del Afrike pa sta značilni izjemno majhna letna vsota padavin in sušnost podnebja. Najbolj namočeni predeli prejmejo nad $1000 \mathrm{~mm}$ padavin, najbolj sušni pa pod $250 \mathrm{~mm}$. Poletno sušno obdobje v Dalmaciji traja dva meseca, v južni Grčiji štiri, na Siciliji šest do sedem, v Libiji pa več kot sedem mesecev (Ogrin 1993).

Natančna opredelitev podnebnih lastnosti zahteva gosto mrežo meteoroloških postaj oziroma razpoložljivost množice podatkov o podnebnih spremenljivkah, zato je za omejevanje izbrane pokrajine podnebje "problematičen« kriterij. Za omejitev Sredozemlja se zdi primernejši hidrogeografski kriterij, saj morju pripada osrednja pokrajinotvorna vloga, vplivalo pa je tudi na družbene značilnosti. Po tej opredelitvi Sredozemlje obsega Sredozemsko morje s pripadajočimi porečji in meje ostajajo nespremenjene. Potekajo po razvodnicah s porečji, ki pripadajo povodjem Črnega in Rdečega morja ter Atlantskega oceana. Večinoma jih je mogoče dokaj natančno določiti, pri čemer pa se ponekod zajedajo daleč v notranjost celin in se pokrajinske značilnosti že zelo razlikujejo od zgoraj opisanih, zato bi le stežka govorili o Sredozemlju, npr. v primerih porečja Rone, Pada pa tudi naše Soče. Del povodja Sredozemskega morja je tudi porečje Nila, ki s svojim zgornjim tokom sega južno od ekvatorja, Sredozemsko morje pa doseže v aridnem območju vzhodne Sahare.

Pri družbenogeografski opredelitvi Sredozemlja so težave še večje, saj je možnih meril veliko in jih je težko ustrezno opredeliti, da bi lahko ločili Sredozemlje od ne-Sredozemlja. Skupne družbenogeografske lastnosti Sredozemlja bi lahko presojali z zgodovinsko-, socialno-, ekonomsko- ali političnogeografskega izhodišča, pri čemer bi ugotovili, da se nekatere od opredelitev boljše in druge slabše prekrivajo. Zagotovo bi nam bile v veliko pomoč tudi raziskave drugih družboslovnih in humanističnih ved, kot so zgodovina, antropologija, etnologija, sociologija. Različni avtorji so si enot$\mathrm{ni}$, da je vloga morja kot povezovalnega člena med ljudstvi, ki so živeli in še živijo na njegovih obalah, zelo pomembna in vidna $v$ njihovi eksistenčni »odvisnosti« od morja (vir hrane in zaslužka), prilagoditvi poselitve in gospodarjenja $\mathrm{z}$ viri na obalah Sredozemskega morja ter razvoju pomorske tradicije (Rotar 1993). Pri opredelitvi bi nam bili v pomoč objektivni, kvantitativni družbenogeografski kazalniki, na primer prebivalstveni ali eko- 
nomski, zagotovo pa bi morali uporabiti tudi kazalnike, ki temeljijo na subjektivnih občutjih, odnosih in ravnanjih prebivalcev. Izbiro pomembnih lastnosti oz. prepoznavnih znakov Sredozemlja, vezano na dojemanje anketiranih (v njem živečih) prebivalcev, so pri svojih raziskavah uporabili tudi Staut, Kovačič in Ogrin (2005; 2007) ter na Hrvaškem Tandarić idr. (2013).

Geografsko opredeljeno območje sredozemske makroregije v Sloveniji obsega šest pokrajin: Koprska brda, Podgorski kras, Čičarijo in Podgrajsko podolje, Brkine in dolino Reke, Kras, Vipavsko dolino in Goriška Brda ter morje Tržaškega zaliva (Perko 1998). Glavne značilnosti so menjavanje flišnih in apneniških kamnin, razmeroma toplo, obsredozemsko podnebje, obmorska lega s samosvojimi dejavnostmi, kot so turizem, pomorstvo ter $\mathrm{v}$ pridelavo zgodnjih pridelkov in posebnih kultur usmerjeno kmetijstvo, poselitev $\mathrm{v}$ tesno zgnetenih gručastih naseljih in nenazadnje litoralizacija. Od sosednjega dinarskega sveta se loči po razlikah v podnebju, rastju in gospodarstvu (Perko in Orožen Adamič 1998, 194). V kolikor pozorneje pregledamo lastnosti navedenih pokrajin, ugotovimo, da se v različni meri zgolj približajo značilnostim Sredozemlja, zagotovo pa na njihove lastnosti vpliva bližina Jadranskega morja kot dela Sredozemskega morja, zato se je zanje kasneje uveljavilo poimenovanje obsredozemske pokrajine Slovenije (Senegačnik 2012).

\section{Metodološka pojasnila}

$\mathrm{V}$ raziskavo o prostorskem dojemanju Sredozemlja v slovenski Istri smo skušali zajeti reprezentativen vzorec prebivalcev, ki živijo v štirih istrskih občinah. Za oblikovanje vzorca smo uporabili metodo kvotnega vzorčenja, ki se nasploh uporablja v trženjskem raziskovanju in raziskavah javnega mnenja, denimo v javnomnenjskih anketah o političnih temah. Namen kvotnega vzorčenja je pridobiti končni vzorec, ki bo reprezentativno odražal razmerja v populaciji na osnovi različnih kategorij, kot na primer spola, etnične pripadnosti, starostnih skupin, regije/kraja bivanja. Vzorčenje po tej metodi ne poteka naključno, temveč je končna izbira vzorca prepuščena izvajalcu (Haralambos in Holborn 1999; Neuman 2006; Bryman 2012). Podatke o razmerjih v širši opazovani populaciji lahko izvajalec pridobi od različnih ustanov, ki so zadolžene za zbiranje informacij, v našem primeru je bil to Statistični urad Republike Slovenije (2019), ki zbira podatke o številu in značilnostih prebivalcev na različnih prostorskih nivojih. Na osnovi podatkov o številu prebivalcev v občinah Ankaran, Izola, Koper in Piran 
smo določili skupno število anket, ki je znašalo 350 in je predstavljalo 0,47 $\%$ polnoletnega prebivalstva na tem območju. V naslednji fazi smo to število prostorsko uravnotežili s številom polnoletnih prebivalcev po posameznih občinah, v nadaljevanju pa je sledilo še spolno uravnoteženje vzorca. Pridobljeni podatki o želenem številu moških in ženskih anketirancev po izbranih občinah so prikazani v preglednici 1.

Preglednica I. Število in deleži polnoletnih prebivalcev v istrskih občinah v letu 20 I8 in preračunano število potrebnih anketnih vprašalnikov po metodi kvotnega vzorčenja

\begin{tabular}{|c|c|c|c|c|c|c|c|}
\hline \multicolumn{2}{|c|}{ Občina } & $\begin{array}{c}\text { Št. pol- } \\
\text { noletnih } \\
\text { prebival- } \\
\text { cev (2018) }\end{array}$ & $\begin{array}{l}\text { Št. pot- } \\
\text { rebnih } \\
\text { anket } \\
\text { (skupno) }\end{array}$ & $\begin{array}{l}\text { Polnole- } \\
\text { tni moški } \\
(2018)\end{array}$ & $\begin{array}{l}\text { Št. pot- } \\
\text { rebnih } \\
\text { anket }(\mathrm{m})\end{array}$ & $\begin{array}{l}\text { Polnole- } \\
\text { tne ženske } \\
(2018)\end{array}$ & $\begin{array}{l}\text { Št. pot- } \\
\text { rebnih } \\
\text { anket (̌̌) }\end{array}$ \\
\hline \multirow{2}{*}{ Ankaran } & Število & 2.726 & 13 & 1.324 & 6 & 1.402 & 7 \\
\hline & Delež (\%) & 3,7 & 3,7 & 48,6 & 46,2 & 51,4 & 53,8 \\
\hline \multirow{2}{*}{ Izola } & Število & 13.390 & 63 & 6.516 & 31 & 6.874 & 32 \\
\hline & Delež (\%) & 18,0 & 18,0 & 48,7 & 49,2 & 51,3 & 50,8 \\
\hline \multirow{2}{*}{ Koper } & Število & 42.922 & 202 & 20.958 & 99 & 21.964 & 103 \\
\hline & Delež (\%) & 57,8 & 57,7 & 48,8 & 49,0 & 51,2 & 51,0 \\
\hline \multirow{2}{*}{ Piran } & Število & 15.187 & 72 & 7.365 & 35 & 7.822 & 37 \\
\hline & Delež (\%) & 20,5 & 20,6 & 48,5 & 48,6 & 51,5 & 51,4 \\
\hline \multirow{2}{*}{ SKUPAJ } & Število & 74.225 & 350 & 36.163 & 171 & 38.062 & 179 \\
\hline & Delež (\%) & 100,0 & 100,0 & 48,7 & 48,9 & 51,3 & 51,1 \\
\hline
\end{tabular}

Vir za drugi, četrti in šesti stolpec preglednice: SURS 2019.

Za potrebe raziskave smo sestavili anketni vprašalnik, skaterim so nato študenti študijskega predmeta Sodobni geografski procesi v Sredozemlju, ki se izvaja na podiplomskem študijskem programu Geografija UP Fakultete za humanistične študije, izvedli anketiranje po vnaprej predvideni prostorski in spolni strukturi vzorca. Anketiranje se je izvajalo od začetka meseca novembra 2018 do konca meseca februarja 2019. Uspeli smo pridobiti 351 izpolnjenih vprašalnikov, ki so bili po posameznih občinah in spolu sogovornikov razporejeni tako, kot prikazuje preglednica 2. Dodatna pozornost je bila pri izvajanju anketiranja namenjena čim enakomernejši zastopanosti sogovornikov iz urbanih in podeželskih območij štirih občin, še posebno v Mestni občini Koper, katere velik del je podeželski. Ob primerjavi s preglednico 1 lahko ugotovimo, da pridobljeni vzorec v preglednici $2 \mathrm{v}$ visoki meri odraža izbrane izhodiščne številčne, prostorske in spolne zna- 
čilnosti prebivalcev na obravnavanem območju (odstopanja pri posameznih kategorijah so manjša od $3 \%$ ).

Preglednica 2. Število in deleži dejansko pridobljenih anket glede na občine in spol anketiranca

\begin{tabular}{|c|c|c|c|c|}
\hline \multicolumn{2}{|c|}{ Občina } & $\begin{array}{c}\text { Št. dejansko pridoblje- } \\
\text { nih anket (skupno) }\end{array}$ & $\begin{array}{c}\text { Št. dejansko pridoblje- } \\
\text { nih anket }(\mathrm{m})\end{array}$ & $\begin{array}{c}\text { Št. dejansko pridoblje- } \\
\text { nih anket }(\check{z})\end{array}$ \\
\hline \multirow{2}{*}{ Ankaran } & Število & 23 & 10 & 13 \\
\hline & Delež (\%) & 6,6 & 43,5 & 56,5 \\
\hline \multirow{2}{*}{ Izola } & Število & 58 & 28 & 30 \\
\hline & Delež (\%) & 16,5 & 48,3 & 51,7 \\
\hline \multirow{2}{*}{ Koper } & Število & 208 & 106 & 102 \\
\hline & Delež (\%) & 59,3 & 51,0 & 49,0 \\
\hline \multirow{2}{*}{ Piran } & Število & 62 & 30 & 32 \\
\hline & Delež (\%) & 17,7 & 48,4 & 51,6 \\
\hline \multirow{2}{*}{ SKUPAJ } & Število & 351 & 174 & 177 \\
\hline & Delež (\%) & 100,0 & 49,6 & 50,4 \\
\hline
\end{tabular}

Analizo anketnih vprašalnikov smo opravili z odprtokodno spletno aplikacijo www.1ka.si, kamor so študenti vnašali pridobljene podatke, ter $\mathrm{z}$ računalniškim programom MS Excel. Pri analizi podatkov smo izvedli tehnike lestvičenja in izračuna deležev frekvenčnih porazdelitev, za prikazovanje pa smo uporabili tudi grafične in kartografske tehnike prikaza, izdelane $\mathrm{z}$ računalniškim programom ArcGIS. V slednjem smo opravili tudi analizo gostote pojava, kjer smo glede na prevladujočo identiteto anketirancev analizirali gostoto izrisanih meja Sredozemlja v Sloveniji. Za izračun gostote linijskega pojava smo uporabili orodje Line Density iz ArcGIS-ove razširitve Spatial Analyst, ki izračuna gostoto linijskih objektov v okolici vsake izhodne celice (ESRI 2020). Metoda deluje tako, da okrog vsake celice izdela krog $\mathrm{z}$ določenim polmerom. Dolžina dela vsake linije se znotraj kroga sešteje, vsota pa se deli s površino kroga. Rezultat je podatek o skupni dolžini izrisanih meja (v kilometrih) na kvadratni kilometer, kjer so vrednosti v izhodnem sloju večje na območjih, kjer je več izrisanih meja. Ta podatek smo nato povprečili in dobili indeks gostote med vrednostma o in 1, da smo dobili nazorno sliko o velikosti relativnih razlik za pojav v prostoru.

Anketni vprašalnik je obsegal tri vprašanja, od katerih je prvo zahtevalo opredelitev anketirančeve identitete na osnovi ponujenih možnih odgovorov (narodnostna, sredozemska, primorska, istrska, evropska). Pri drugem vprašanju smo anketirance pozvali, da opredelitev Sredozemlja 
utemeljijo s ponujenimi odgovori o prepoznavnih lastnostih naravnega okolja (močni vetrovi, kamnita pokrajina, zimzeleno rastlinstvo, morje, sonce in poletna suša), s prehranjevalnimi posebnostmi oziroma t. i. mediteransko dieto (več sadja in zelenjave, oljčno olje, kruh in testenine, ribe, manjša poraba rdečega mesa in maščob živalskega izvora) ter $\mathrm{z}$ vedenjskimi vzorci (opoldanski premor - siesta, druženje na javnih in tudi odprtih prostorih, pomen družine in vloge matere, poudarjena religiozna dediščina - obisk verskih obredov in romanja, spoštovanje kulturne tradicije). Anketiranci so se do vseh ponujenih odgovorov opredelili z izbiro na petstopenjski vrednostni lestvici od »Najbolj pomembno« do »Skoraj nepomembno«, vrednosti pa se znotraj enega sklopa niso smele ponavljati. Tretje vprašanje $v$ anketi je bilo pravzaprav naloga, ki je zahtevala, da anketiranci na priloženi zemljevid Slovenije vrišejo mejo med »sredozemskim« in »nesredozemskim« delom Slovenije ter navedejo, kaj je bil glavni motiv izrisa meje. Zanimalo nas je torej, v kolikšni meri prebivalci istrskih občin izražajo sredozemsko identiteto, kako prepoznavajo oziroma kaj po njihovem mnenju opredeljuje Sredozemlje ter kako ga v Sloveniji prostorsko omejujejo.

\section{Analiza rezultatov anketne raziskave}

Anketirane smo uvodoma prosili, da po pomenu opredelijo svojo identiteto. Večina vprašanih je kot "Najbolj pomembno« in "Zelo pomembno« izbrala narodnostno (skupaj $69 \%$ odgovorov), sledili sta primorska (64\%) in istrska identiteta (51\%). Presenetilo nas je, da je bil delež kategorij »Najbolj pomembno« in »Zelo pomembno« pri slednji najmanjši, odgovori pa so bili enakomerneje porazdeljeni od najbolj do manj pomembne. Sredozemsko in evropsko identiteto je večina vprašanih ocenila kot "Manj pomembno《 in »Skoraj nepomembno«. Sredozemska identiteta, ki nas je posebej zanimala, je bila najpomembnejša le za $3 \%$ in zelo pomembna za $11 \%$ vprašanih (slika 1). Rezultati raziskave Stauta, Kovačiča in Ogrina (2005) so pokazali, da je anketirancem najpomembnejša primorska identiteta, blizu jim je bila narodnostna, nato sta sledili sredozemska in evropska ter kot zadnja istrska. Med slednjimi tremi opredelitvami so bile razlike zelo majhne. Avtorji so pojasnili, da na rezultate zagotovo vpliva pretežni del anketiranih v mestnih naseljih slovenske Istre, med katerimi je veliko priseljencev in zanje pripadnost slovenski Istri ni pomembna. Biti Sredozemec oziroma prisvajati si sredozemske poteze pa je sodobno, zato so pričakovali, da se bodo anketiranci $\mathrm{z}$ večjim deležem opredelili za Sredozemce, kot bi jim 


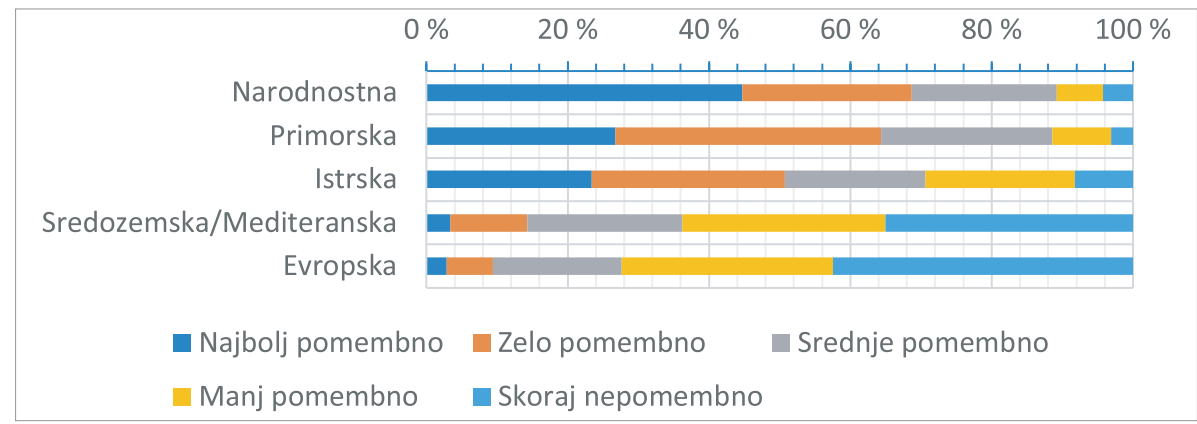

Slika i. Stopnje pomembnosti poistovetenja anketirancev s podanimi identitetami

to glede na pokrajino, v kateri živijo, in stil življenja pripadalo. V kasnejši raziskavi, ki je zajela prebivalce širše obsredozemske regije (Goriška, Kras, Pivka, Brkini z dolino Reke), Ljubljano z okolico ter povzela rezultate ankete med prebivalci slovenske Istre iz predhodne raziskave, so se anketirane skupine v različni meri opredelile kot Sredozemci. Po pričakovanju avtorjev je bil največji delež Sredozemcev med anketiranimi prebivalci slovenske Istre $(78,4 \%)$, tako se je opredelilo $65 \%$ anketiranih s Krasa, $61 \%$ anketiranih z Goriške, 56 \% vseh anketiranih v obsredozemskih pokrajinah in polovica anketiranih v Brkinih z dolino Reke. V Ljubljani z okolico pa se je za Sredozemce opredelilo manj kot petina vprašanih (Staut, Kovačič in Ogrin 2007).

Pri opredelitvi Sredozemlja z naravnimi (pokrajinskimi) lastnostmi je večina anketirancev kot »Najbolj pomembno« izbrala morje (69 \% vprašanih), če pa prištejemo še opredelitev »Zelo pomembno«, potem je delež znašal kar $89 \%$. Podatek nas ni presenetil; kolikšen je pri vrednotenju pomen imena (Sredozemlje je predvsem Sredozemsko morje s pripadajočimi robnimi morji in obalami) ter kolikšen posredni vpliv morja na naravne in družbene lastnosti, lahko le ugibamo. Na drugem mestu po pomenu je sredozemsko podnebje $\mathrm{z}$ veliko sonca in sušo, ki ga je 37 \% vprašanih ocenilo kot "Zelo pomembno«, $17 \%$ pa kot "Najbolj pomembno«. Zimzeleno rastje je bilo prevladujoče ocenjeno kot "Srednje pomembno« (30 \%) in "Zelo pomembno" (28 \%), pogosti močnejši vetrovi in kamnitost kraškega površja pa sta bila prevladujoče ocenjena kot "Skoraj nepomembna« (30 in $34 \%$ ) in »Manj pomembna« (29 in 30 \%). Pripadajoči deleži ocenam pomembnosti oziroma nepomembnosti ponujenih naravnih lastnosti Sredozemlja so prikazani v sliki 2. Večja pomembnost podnebja pri opredelitvi Sredozemlja, v primerjavi z rastlinstvom, vetrovnostjo in kamninami, 
je po naših predvidevanjih povezana s subjektivnim občutenjem toplejšega podnebja v istrskih občinah, vročih poletij in pogostejšega pomanjkanja padavin. Naravno sredozemsko zimzeleno rastlinstvo pri nas ni razširjeno, če bi ponudili kot odgovor uspevanje oljke, pa bi bil vrstni red morda drugačen. Vetrovnost bi utegnila pridobiti na pomenu, če bi v anketo zajeli tudi prebivalce občin v Vipavski dolini, sicer pa so močnejši etezijski vetrovi poleti značilni za vzhodno Sredozemlje in mistral v zahodnem Sredozemlju. Razširjena kamnitost površja na sredozemskih obalah in zlasti otokih je povezana z zelo zastopanimi apnenčastimi kamninami, s krčenjem rastlinskega pokrova zaradi sečnje lesa, paše in požarov v naravi ter posledično erozijo prsti. V naših obsredozemskih pokrajinah pa je tudi na Krasu zaraščanje večinoma skrilo kamnito površje.

Naslednji sklop ponujenih odgovorov za opredelitev Sredozemlja je bil povezan s prehrano, $\mathrm{z}$ uporabo oljčnega olja, rib in morskih sadežev, sadja in zelenjave, kruha in testenin ter maščob živalskega izvora in rdečega mesa. Manjšo uporabo slednjega je kar 56 \% vprašanih ocenilo kot »Skoraj nepomembno«, skupaj s kategorijo »Manj pomembno « pa je delež znašal 79 $\%$. Nasprotno je 79 \% vprašanih uporabo oljčnega olja ocenilo s kategorijama »Najbolj pomembno« in »Zelo pomembno« v prehrani Sredozemlja, s $66 \%$ pa sta bili isti kategoriji zastopani tudi pri ribah. Kruh in testenine ter sadje in zelenjava so prejeli enakomerneje razporejene ocene. Pri slednjih je bil najmanjši delež (8 \%) evidentiran pri odgovoru "Skoraj nepomembno«, pri kruhu in testeninah pa je enak delež odgovorov (8 \%) zabeležil odgovor »Najbolj pomembno«. Pripadajoči deleži ocen pomembnosti oziroma nepomembnosti pri ponujenih lastnostih prehrane v Sredozemlju so prikazani v sliki 2. Predvidevamo, da veliko vprašanih pozna »koristnost mediteranske diete« za zdravje, pri vrednotenju ponujenih odgovorov pa so verjetno izhajali tudi iz lastnih izkušenj, bodisi poznavanja receptov, priprave ali uživanja hrane na poteh po Sredozemlju in ne-Sredozemlju. Za mediteransko prehrano naj bi bili značilni večja poraba žit in oljčnega olja ter manjša poraba mesa in živalskih maščob (Krese in Baskar 1993). Naši anketiranci ne pripisujejo večjega pomena kruhu in testeninam, niti manjši porabi rdečega mesa in živalskih maščob. Pomembna je uporaba oljčnega olja, ki je dandanes zelo razširjena, ni pa nujno prevladujoča niti v slovenski Istri, kjer je največ »domačega« oljčnega olja. Podobno so ribe vsaj deloma vir živalskih beljakovin tudi v pokrajinah, ki so bolj oddaljene od morja. Iz odgovorov sklepamo, da je prehrana večine vprašanih raznolika, ker so živila dostopna na svetovnem trgu in manj odvisna od krajevne pridelave ter pogojev 


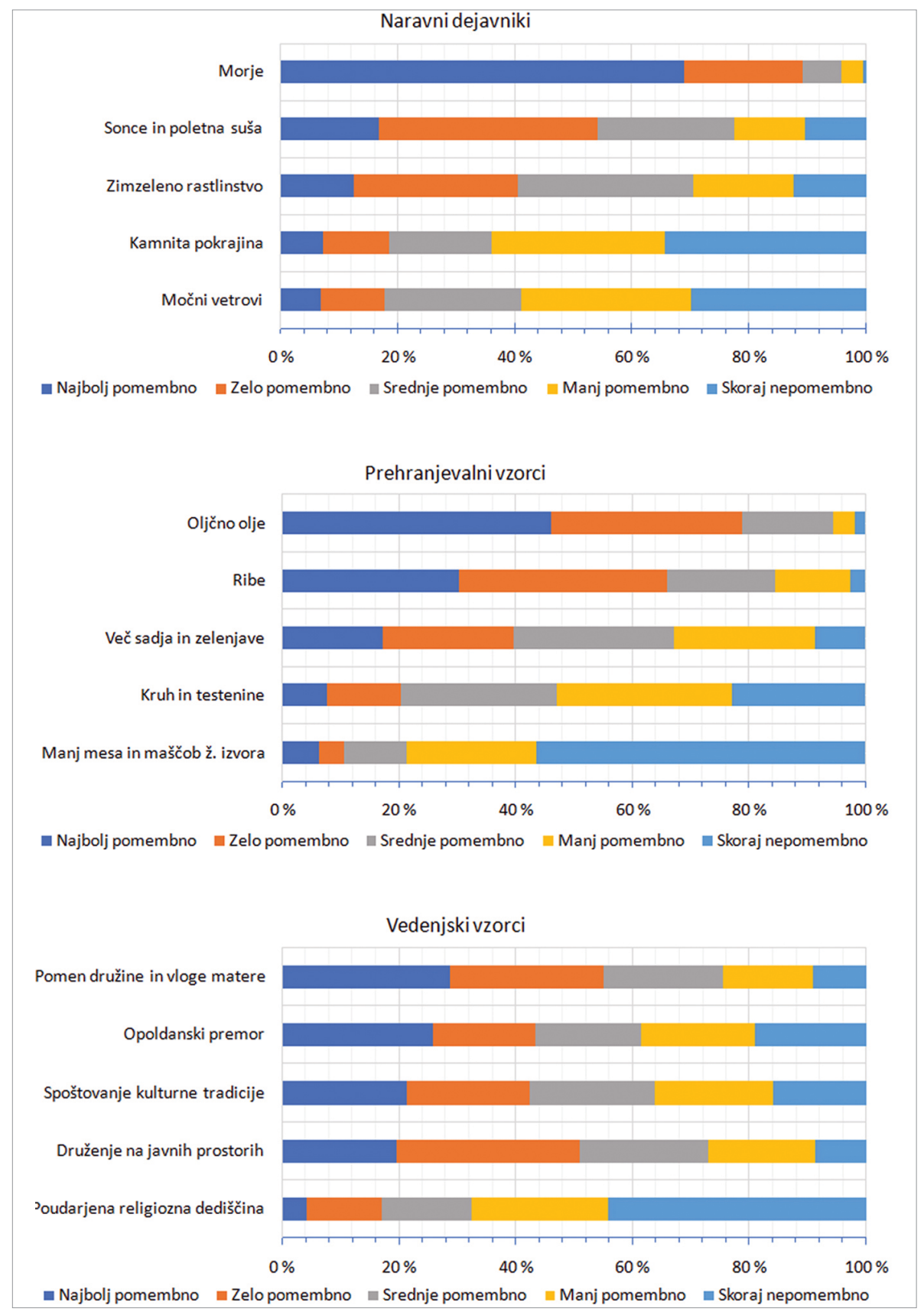

Slika 2. Odgovori anketirancev glede pomembnosti oziroma nepomembnosti ponujenih kriterijev za opredelitev Sredozemlja 
zanjo. Menimo, da glede tega vprašanja ne bi bilo opaznih razlik, četudi bi območje anketiranja razširili.

Zadnje vprašanje pri opredeljevanju Sredozemlja je ponudilo odgovore, ki so povezani $\mathrm{z}$ načinom življenja, vrednotami in s kulturno tradicijo. Tukaj je morda $v$ največji meri prevladovala subjektivnost izbire glede na lastne vrednote, izkušnje in znanje oziroma informiranost. Na primer, kaj posameznik razume kot "Spoštovanje kulturne tradicije«, lahko zgolj ugibamo ali pa nas, če nismo verujoči, izvajanje religioznih praks verjetno manj zanima in jim ne bomo pripisali večjega pomena. Ocene so bile pri vseh odgovorih veliko enakomerneje razporejene kakor pri naravnih (pokrajinskih) lastnostih in prehrani. Največji delež od vseh je s $44 \%$ pripadel oceni "Skoraj nepomembno« pri religiozni dediščini (verski obredi in romanja), sledilo je druženje na javnih prostorih, ki je bilo kot "Zelo pomembno" izpostavljeno s strani $31 \%$ anketirancev. Če združimo oceni »Najbolj pomembno« in "Zelo pomembno«, je za $55 \%$ anketiranih pomembna značilnost Sredozemlja vloga družine in matere ter za polovico druženje na javnih prostorih, obratno pa so največji deleži pri ocenah »Skoraj nepomembno« in "Manj pomembno « pri religiozni dediščini (67 $\%)$, opoldanskem počitku ( $38 \%$ ) in spoštovanju kulturne tradicije (36 \%), kot prikazuje tudi slika 2 .

\section{Prostorska opredelitev meje Sredozemlja v Sloveniji}

Tretja naloga je obsegala razmejitev med sredozemskim in nesredozemskim delom Slovenije, svojo odločitev za izris meje pa so morali anketiranci nato pojasniti $\mathrm{z}$ navedbo vodilnega kriterija. Na sliki 3 so prikazane črte, ki so jih kot meje zarisali anketiranci, v zgornjem desnem kotu pa je za lažjo predstavo prikazano $\mathrm{z}$ geografskimi regionalizacijami opredeljeno območje obsredozemske Slovenije (Perko 1998; Jeršin Tomassini in Janžekovič 2015). Iz 351 izpolnjenih anket smo pridobili 341 izrisanih meja, izmed katerih smo v naslednji fazi izločili še štiri, saj je bil njihov potek nejasno opredeljen. Opazimo lahko, da se med anketiranimi prebivalci istrskih občin pojavlja zelo različno mnenje o tem, katera območja še uvrščamo k obsredozemskim pokrajinam in katera ne (slika 3). Nekatere črte so izrisane že v zaledju obalnih mest, nekatere pa se zajedajo celo v alpski svet na severu ter potekajo mimo Logatca in Cerknice proti Goteniški gori na jugovzhodu. Kljub raznolikosti v izrisanih potekih meja lahko opazimo dve zgostitvi: prva poteka čez Kras vse do severovzhodne meje slovenske Istre, druga, izrazitejša, pa po jugozahodnem vznožju Trnovskega gozda in 


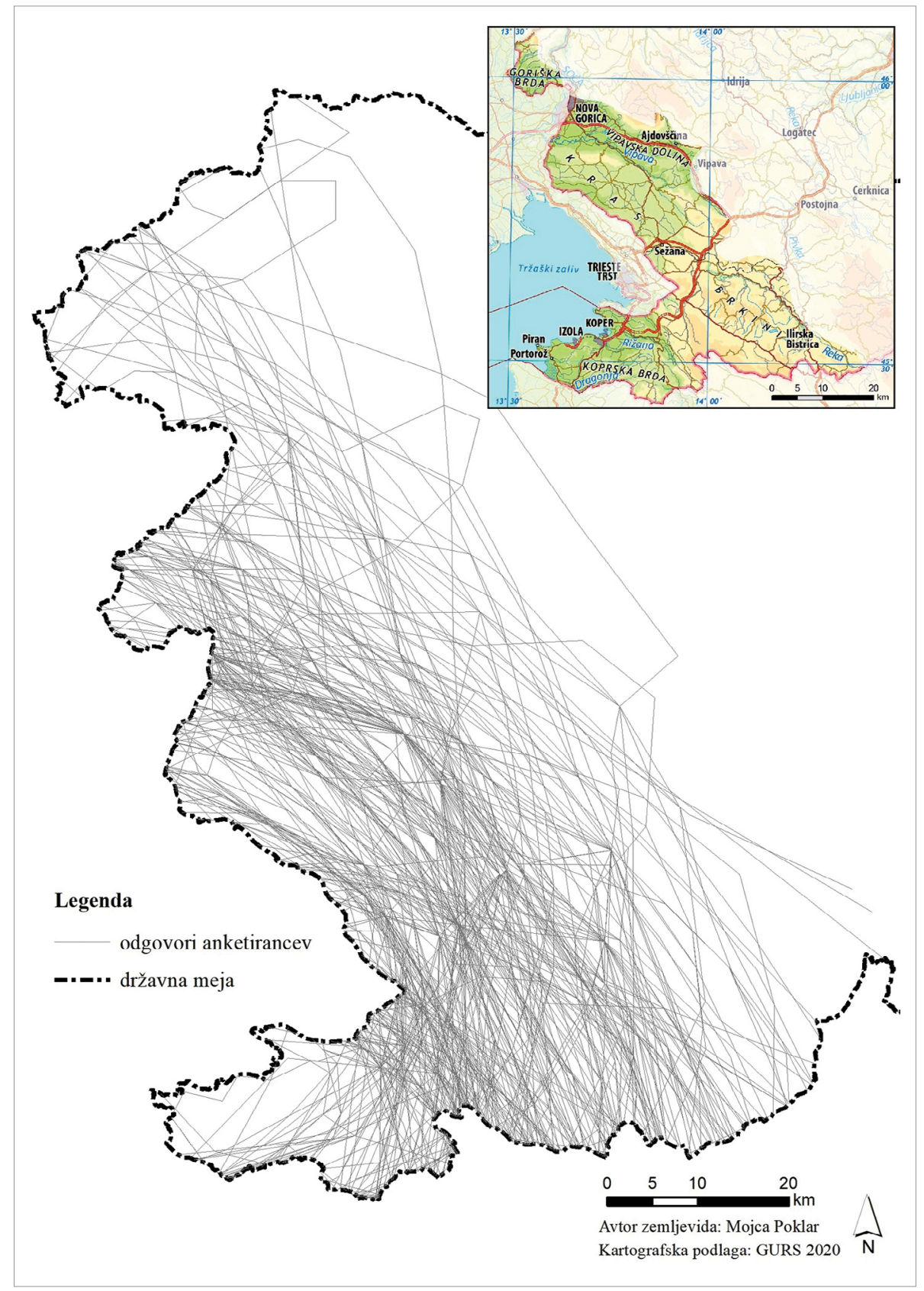

Slika 3. Izrisane meje med sredozemskim in nesredozemskim delom Slovenije ter z regionalizacijo opredeljene obsredozemske pokrajine (Perko 1998) 
Nanosa do Vremščice. Območje v Sloveniji, za katerega vsi anketiranci menijo, da pripada Sredozemlju, vključuje obalna mesta z ozkim pasom zalednega gričevja nad Izolo. Podobno so pokazali rezultati raziskave (Staut, Kovačič in Ogrin 2005), kjer so prav vsi anketiranci menili, da sta slovenski del Tržaškega zaliva in obmorski pas slovenske Istre $\mathrm{z}$ delom zalednega gričevja (nad Izolo in Piranom) del Sredozemlja. Rezultati kasnejše raziskave (Staut, Kovačič in Ogrin 2007) so podobni našim in tu sta bili prav tako vidni dve zgostitvi izrisanih črt. Zahodnejša je potekala okvirno po severovzhodni meji slovenske Istre, vzhodnejša pa po jugozahodnem vznožju visokih dinarskih planot. Nekateri anketiranci so mejo povlekli preko najvišjih gora Julijskih Alp, čez Cerkljansko in Ljubljansko barje proti Kočevju in Beli krajini, vsi anketiranci pa so menili, da sta slovenski del Tržaškega zaliva in obmorski pas slovenske Istre $\mathrm{z}$ bližnjim zalednim gričevjem del Sredozemlja.

Na sliki 4 je prikazan potek meja glede na opredelitev najpomembnejše identitete. Izbrali smo samo tri, ki predstavljajo večje deleže: narodnostno, primorsko in istrsko. Opazimo lahko, da so anketiranci, ki se najbolj poistovetijo $\mathrm{z}$ narodnostno ali s primorsko identiteto, potegnili mejo Sredozemlja v veliki meri skladno z obsegom obsredozemskih pokrajin po Perkovi regionalizaciji (1998). Tako je od 140 anketirancev, ki so kot najpomembnejšo izbrali narodnostno identiteto, skoraj petina (17 \%) postavila mejo znotraj 10-kilometrskega območja ob meji obsredozemskih pokrajin, medtem ko je bilo $55 \%$ takih meja, pri katerih je vsaj polovica padla znotraj prej omenjenega območja. Pojavljajo se sicer odstopanja, kjer je dobra petina anketirancev izrisala mejo južneje, na Kraškem robu, kar nekaj pa je bilo takšnih, ki so mejo nadaljevali severneje, vse do alpskega sveta.

Pri primorski identiteti je "sovpadanje« primerljivo, saj je bilo od 74 anketirancev, ki so kot najpomembnejšo izbrali primorsko identiteto, 16 $\%$ takih, ki je mejo izrisalo v celoti znotraj 10-kilometrskega območja ob meji obsredozemskih pokrajin, medtem ko je bilo kar $66 \%$ takih meja, katerih je vsaj polovica padla znotraj prej omenjenega območja. Do odstopanj prihaja predvsem $\mathrm{v}$ južnem delu zgostitve črt, kjer njen potek v več kot polovici primerov sledi severovzhodni meji slovenske Istre in ne obsega Brkinov z dolino Reke ter Podgorskega krasa, Čičarije in Podgrajskega podolja. Kljub temu lahko opazimo, da na sliki 4 temnomodro območje, ki prikazuje zgostitev narisanih meja, v večini poteka skladno $\mathrm{z}$ rdečo črto, ki prikazuje mejo obsredozemskih pokrajin po Perkovi regionalizaciji (1998). 


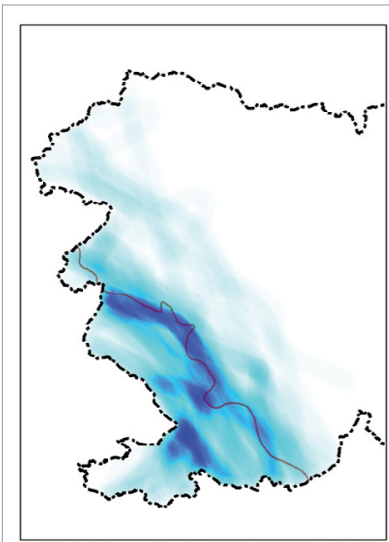

a) narodnostna identiteta

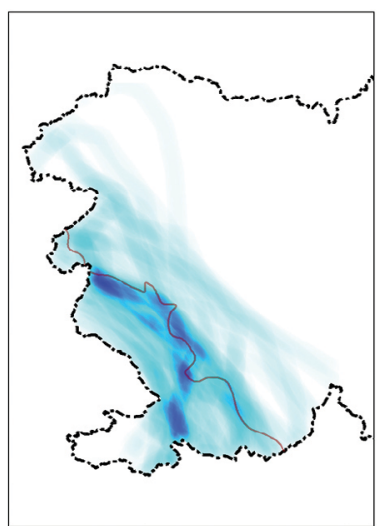

b) primorska identiteta

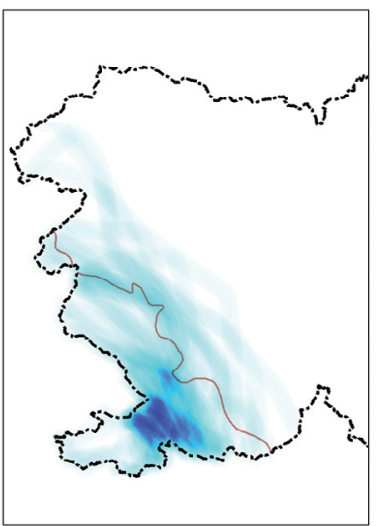

c) istrska identiteta

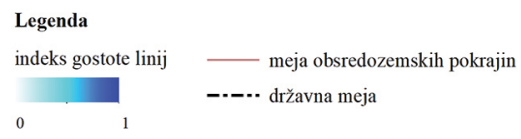

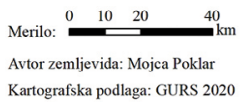

Slika 4. Indeks gostote izrisanih meja med sredozemskim in nesredozemskim delom Slovenije glede na prevladujočo identiteto (z dodano mejo obsredozemskih pokrajin, Perko 1998)

Večje razlike $\mathrm{v}$ primerjavi $\mathrm{z}$ začrtano in dejansko mejo obsredozemskih pokrajin je opaziti pri tistih anketirancih, ki so kot najpomembnejšo izbrali istrsko identiteto. Takih je bilo skupno 72, od tega pa je le dobrih $5 \%$ postavilo mejo znotraj 10-kilometrskega območja ob meji obsredozemskih pokrajin. Od vseh zarisanih meja je le $39 \%$ takšnih, kjer vsaj polovica pade znotraj omenjenega območja. Zemljevid gostote črt kaže na izrazito drugo značilnost, in sicer na največjo zgostitev črt na območju Kraškega roba, kar se ujema $\mathrm{z}$ naravnogeografsko mejo Istre.

Pri utemeljitvi kriterija za izris meje so anketiranci najpogosteje navedli podnebje in vpliv morja, sledilo je vreme, sredozemsko rastlinstvo in oljka, kultura in tradicija ter primorska mesta in kraji. Med ostalimi kriteriji je bila zanimiva večkrat omenjena izobrazba oziroma pridobljeno znanje, drugi prikazani motivi na sliki 5 pa so bili omenjeni redkeje ali posamično. V starejši raziskavi so prebivalci slovenske Istre kot najpomembnejši dejavnik pri določanju meje med Sredozemljem in ne-Sredozemljem v Sloveniji navedli rastje, ki zajema tako naravno kot kulturno (omenilo ga je 27,6 \% vprašanih), sledilo je podnebje (22\%), morje (12\%), značaj ljudi $(8,9 \%)$ in še nekaj manj zastopanih odgovorov (Staut, Kovačič in Ogrin 2005). V kasnej- 


\section{primorska mesta in kraji
kultura in tradicija}
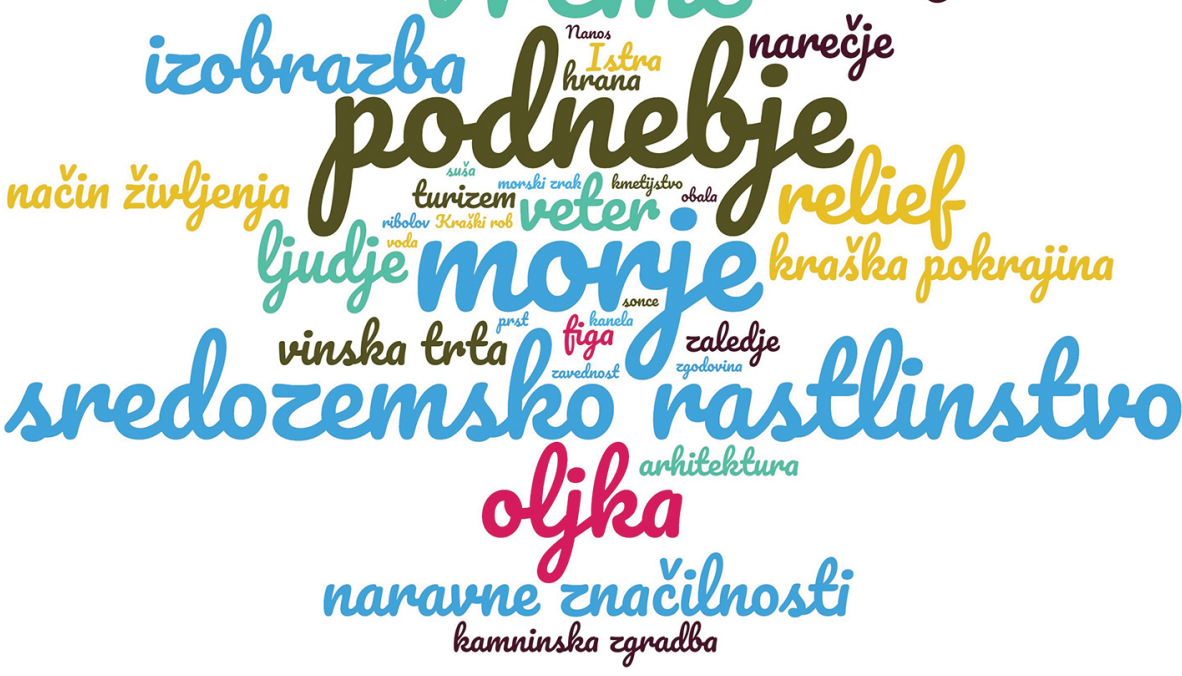

Slika s. Razlogi za utemeljitev izrisa meje Sredozemlja na zemljevidu

ši raziskavi, ki je zajela anketirance $\mathrm{v}$ širših obsredozemskih pokrajinah in tudi v Ljubljani z okolico (Staut, Kovačič in Ogrin 2007), je bil prevladujoči razlog za razmejitev sredozemskega in nesredozemskega dela Slovenije podnebje (40 \% odgovorov), ki je zajelo širok spekter odgovorov (podnebje, burja, temperature, padavine), sledila sta morje (morje, njegova bližina ali vplivi, obala) z $18 \%$ in rastje (zimzeleno, naravno in kulturno rastje, figa, oljka in meje njene razširjenosti) s $14 \%$. V raziskavi Tandarića idr. so bili ugotovljeni podobni razlogi za določitev meje sredozemskega in nesredozemskega dela Hrvaške. Vodilni kriterij je bilo podnebje $(71,7 \%)$, sledilo je morje oziroma obala $(57,5 \%)$, rastlinstvo (50 \%), relief (37,5\%), miselnost (35 $\%)$ ter z manjšimi deleži hrana, arhitektura in drugi dejavniki.

\section{Sklep}

Rezultati raziskave, izvedene med prebivalci istrskih občin, so pokazali, da za večino vprašanih sredozemska identiteta ni pomembna, da se jih večina najprej opredeljuje kot Slovenci ali Primorci in nato kot Istrani. Pri 
opredelitvi Sredozemlja so anketirani enotnejši, ko so izbirali med naravnimi značilnostmi, kjer največjo pokrajinotvorno vlogo pripisujejo morju in podnebju, kar nas ne preseneča. Kot smo omenili v razpravi, izbira morja morda $\mathrm{v}$ večji meri izhaja iz poimenovanja regije in povezanosti ljudi $\mathrm{z}$ morjem, sprašujemo pa se, $\mathrm{v}$ kolikšni meri bi znali pojasniti izbiro morja kot naravnega merila. Da so velik pomen pri opredelitvi Sredozemlja pripisali »soncu in suši«, je pričakovano, saj je podnebje tisti pokrajinski dejavnik, ki močno vpliva na vire okolja (vodne vire, rastlinstvo, rodovitnost prsti), rabo tal in pogoje za človekove dejavnosti. Dokaj enotni so bili anketiranci tudi pri vrednotenju lastnosti prehrane, kjer so največji pomen pripisali oljčnemu olju in ribam. Prvo je zagotovo povezano z razširjenostjo in gojenjem oljk v Sredozemlju, drugo s tradicijo ribištva, pri izbiri pa so bile po naših predvidevanjih pomembne tudi lastne izkušnje. Pri tretji skupini ponujenih kriterijev za opredelitev Sredozemlja, ki so povezani s kulturo in načinom življenja, so bile ocene pomembnosti oziroma nepomembnosti zelo razpršene in jih težko pojasnimo. Zagotovo so odločitve še v večji meri prepuščene subjektivnosti anketirancev, ki morda niti nimajo »oprijemljivih informacij«, na osnovi katerih bi lahko presojali. So to lastna ali posredovana doživetja, informacije iz filmov, knjig in drugih medijev, je poznavanje povezano s formalnim izobraževanjem? Upoštevati pa moramo še, da se »družbene prakse« tudi spreminjajo.

Pri risanju meje med sredozemskim in nesredozemskim delom Slovenije lahko opazimo velike razlike, saj so nekateri slednjo začrtali v bližnjem zalednem območju obalnih mest, drugi pa vse od najvišjih vrhov alpskega sveta na severu do Kočevskega na jugovzhodu. Kljub temu sta dobro vidni dve zgostitvi črt, kjer severnejša sledi Vipavski dolini oziroma jugozahodnem vznožju Trnovskega gozda in Nanosa do Vremščice, južnejša pa poteka po južnem delu Krasa. Obe zgostitvi se združita na območju severozahodnega dela Podgrajskega podolja in zaključita na vzpetinah slavniškega hribovja. V primerjavi z mejo obsredozemskih pokrajin (Perko 1998) ti zgostitvi ne obsegata Goriških Brd, Brkinov z dolino Reke ter Podgrajskega podolja in Čičarije. Razloge za tako razmejitev gre iskati predvsem v poznavanju »domače pokrajine«, saj prebivalci istrskih občin bližnje pokrajine boljše poznajo od nekoliko bolj oddaljenih, verjetno pa je razlog tudi v čustveni navezanosti Istranov na svoje območje. To pojasnjujejo izrisane meje anketirancev, ki so kot najpomembnejšo identiteto opredelili istrsko in meje začrtali po naravnogeografski meji, to je Kraški rob. Ker je bila raziskava opravljena le med prebivalci slovenske Istre, predpos- 
tavljamo, da je pogled na mejo med sredozemskim in nesredozemskim delom Slovenije nekoliko izkrivljen in bi bil drugačen, če bi zajeli anketirance tudi iz drugih obsredozemskih pokrajin. Enako ugotavljajo tudi Staut, Kovačič in Ogrin (2005), ki v svojem prispevku omenjajo t. i. »istrocentrični pogled « na opredelitev in obseg Sredozemlja v Sloveniji, ko zaradi prostorske zgoščenosti anketirancev ti zavzemajo podobna stališča. Zavedamo se, da so tudi rezultati naše raziskave do neke mere »istrocentrični«. Da bi dobili celovitejši pogled in spoznali razlike v dojemanju Sredozemlja v Sloveniji, bi morali opraviti raziskavo na širšem območju, ki bi zajela prebivalce iz vseh obsredozemskih pokrajin.

S prispevkom smo na primeru Sredozemlja želeli opozoriti, kako težavno je opredeljevanje pokrajinskih enot in regij ter da vse razmejitve $\mathrm{v}$ pokrajini zahtevajo sprejemanje kompromisov, posplošitve in le $\mathrm{v}$ določeni meri odgovarjajo različnim merilom. Kot so povzeli Tandarić idr. (2013), nobena omejitev ne bo zajela vseh lastnosti Sredozemlja, lahko pa se opredeli osrednje območje, kjer so prepoznane lastnosti zelo jasno izražene in prehodna območja, kjer se izrazitost lastnosti zmanjšuje in se prepletajo $\mathrm{z}$ lastnostmi sosednjih območij.

\section{Zahvala}

Avtorji se zahvaljujejo dr. Nataši Kolega in študentom UP Fakultete za humanistične študije: Eriki Mahnič, Igorju Mesarju, Martinu Mihaliču, Žigi Mlinarju, Niki Nose, Diani Palčič, Hani Udovič in Danijeli Vaš.

\section{Viri in literatura}

\section{Literatura}

Allen, D. Harriet. 2001. Mediterrranean Ecogeography. London: Prentice Hall. Baskar, B. 2002. Dvoumni Mediteran. Koper: Založba ZRS.

Bryman, A. 2012. Social Research Methods. New York: Oxford University Press. Haralambos, M., in M. Holborn. 1999. Sociologija: teme in pogledi. Ljubljana: DZS.

Krese Baskar, M., in B. Baskar. 1993. "Mediteranska prehrana.« Časopis za kritiko znanosti 21 (158-159): 69-81.

Neuman, W. L. 2006. Social Research Methods: Qualitative and Quantitative Approaches. Boston, MA: Pearson. 
Ogrin, D. 1993. »(Sub)mediteransko podnebje v Sloveniji.« Časopis za kritiko znanosti 21 (158-159): 25-34.

Perko, D. 1998. »Regionalizacija Slovenije«. Geografski zbornik 38: 12-57.

Perko, D., in M. Orožen Adamič, ur. 1998. Slovenija - pokrajine in ljudje. Ljubljana: Mladinska knjiga.

Rotar, B. 1993. »Kje je Mediteran?« Časopis za kritiko znanosti 21 (158-159): $15-24$.

Senegačnik, J. 2012. Slovenija in njene pokrajine. Ljubljana: Modrijan.

Staut, M., G. Kovačič in D. Ogrin. 2005. »Prostorsko dojemanje Sredozemlja v slovenski Istri. Analiza s pomočjo teorije mehkih množic."Annales, Ser. hist. sociol, 15 (2): 427-36.

Staut, M., G. Kovačič in D. Ogrin. 2007. »Prostorsko dojemanje Sredozemlja v Sloveniji: (ne)skladje med dojemanjem in fizičnimi opredelitvami."Acta geographica Slovenica 47 (1): 105-31.

Tandarić, N., M. Maček, M. Cvitanović, I. Tekić, M. Flegar, A. Okmaca in J. Tvrdojević. 2013. »Percepcija prostornog obuhvata Sredozemlja u hrvatskoj.« Geoadria 18 (2): 181-97.

\section{Spletni viri}

ESRI. 2020. »How Line Density Works.« https://desktop.arcgis.com/en/arcmap/10.3/tools/spatial-analyst-toolbox/how-line-density-works.htm.

Jeršin Tomassini, K., in M. Janžekovič. 2015. Geografija 9. Ljubljana: Zavod RS za šolstvo. http://www.dlib.si/?URN=URN:NBN:SI:DOC-SW38L4XG.

SURS. 2019. Statistični urad Republike Slovenije. https://pxweb.stat.si/ SiStatDb/pxweb/sl/10_Dem_soc/.

\section{Summary}

Definition and limits of the Mediterranean in Slovenia, according to the residents of Slovene Istria

This chapter presents the results of a survey that sought to define the spatial borders of the Mediterranean region in Slovenia and was conducted among the inhabitants of four municipalities of Slovene Istria. The Mediterranean is a complex phenomenon whose identity evolved gradually from pre-ancient times to the present. When defining such a multi-layered and complex term from the spatial aspect, one faces many dilemmas and challenges, as there is no single and simple criterion to distinguish the Mediterranean 
areas from the non-Mediterranean ones. In line with the previous research, the authors designed a survey and then obtained a sample of 351 completed questionnaires using the quota sampling technique, which succeeded to reflect the numerical, spatial and sexual characteristics of the population in the area. The study examined the perception of the Mediterranean concerning identity, the elements of the natural environment, and the nutritional and behavioural patterns that are expected to be characteristic of the Mediterranean. Special attention was paid to the spatial perception of the Mediterranean, where respondents were asked to draw its boundaries on a pre-prepared map. The authors found interesting links between respondents' self-identification and individual spatial patterns of the borders of Mediterranean subregions in Slovenia. Respondents, who identified themselves mostly with national or Littoral identity, tended to follow the actual boundaries of the Mediterranean subregions when drawing borders, while those with a predominantly Istrian identity often drew borders much further south, in the north-eastern part of the Slovene Istria. When relating to the general concept of the Mediterranean, the respondents highlighted the importance of the sea and the climate (natural environment), olive oil and fish (nutritional patterns), as well as of socializing in public spaces and the role of the family together with the matriarchal society (behavioural patterns). 